\author{
S.F. Legenchuk, PhD in Economics, Prof. \\ I.R. Polishchuk, Cand. Ec.Sc., Associate Prof. \\ Zhytomyr State Technological University
}

\title{
ORGANIZATIONAL AND METHODICAL APPROACHES TO DISCLOSURE OF INCOME DISTRIBUTION IN INTEGRATED REPORTING
}

\begin{abstract}
The essence of the integrated reporting is described. Preconditions and problems when introducing the integrated reporting are presented. The information requests of integrated reporting users are described. The necessity of reflection of all types of capital, namely, natural, social, human and intellectual in the integrated reporting are revealed. The main advantages of compiling the integrated accounts for the enterprise are established: a broader perspective of consideration of the activity; the improvement of accounting policy as a result of integration of the principles of sustainable development into activity; increasing the trust of workers and consumers in the safety of technological processes and products for environment. For the wider introduction of the integrated reporting it is necessary to develop the methodological provision for accounting in accordance with the principles of sustainable development to ensure the reliability of the indices obtained; it is necessary to select the optimal list of indices that can meet the information needs of all users, in particular, investors, the state, auditors, society, creditors, consumers, employees, management personnel, academics, and the media. The main tasks and principles of compilation of the integrated reporting are presented. Orientation to the future, materiality, demand, integrity, reliability, completeness, periodicity, consistency, timeliness, interpretation, and comparability are suggested as the principles of integrated reporting. The issue of the necessity of conducting the external audit of the data verification of the integrity reporting is highlighted. The algorithm of profit distribution depending on the chosen strategy of enterprise development is proposed. When directing net profits for the development of production, the authors identify the following three strategies: insufficient upgrades, upgrades at the level of wear and the advanced renewal of non-current assets. It is proposed to choose the strategy for the extended renewal of non-current assets, which will increase the scope of activities and the net profit in the future.

Keywords: integrated reporting; sustainable development concept; income distribution; financial reporting; strategy.
\end{abstract}

Settlement of the problem. The instability of the current legislation, stationary vibration of dollar rate, the increase of society need to obtain reliable information about social protection and motivation among workers, charities, the application of power saving technologies, and the necessity to provide consumers with guaranties about safety and quality of technological process and production results themselves for a human and environment cause the conditions in which financial reporting doesn't disclose complete and reliable information about all the aspects of enterprise's activities. That is why we are faced with the urgent need to compile the integrated reporting about separate kinds of enterprise's capital, namely natural, social, human and intellectual, However, it requires from accountants to possess some extra occupational capacities.

Analysis of the latest researches and publications. Nowadays, the issue of content filling and compiling procedure aspects for the integrated reporting (where the main information about enterprise's capital is reflected) is rather actual, and the researches of such scientists as Atamas P.J., Atamas O.P. [1], Bezverhyj K. [2], Di Piaza and Jekklz R. [3], Domashenko Ju.V. [4], Jershova N.Ju. [5], Kostyrko R.O. [6], Lohanova N.O. [7], Prodanchuk M. [8] show that, However, in spite of great work of the mentioned above authors, the issues of the reporting structure, the principles of its compiling, and the advantages for an enterprise and society still remain unexamined enough.

Purpose of the research is to specify the integrated reporting structure and the advantages of its compiling for society, in particular in the part of profit distribution.

Statement of the research. Capital has been one of the principal objects and the capital information has always been in great need among interested users since the appearance of double entry bookkeeping. The development in economics, especially during last two decades, is characterized by tendencies of post industrialization and globalization and caused the transformation in understanding of capital content filling as the bookkeeping object that is characterized by appearance of its new types with their specific features that influence the order of their bookkeeping reflection.

The beginning of the XX-th century in the bookkeeping development was marked with «tragic» events that was connected with the scandal called «Anron Case», which did much harm both the reputation of accounting occupation in the world and caused the beginning of a new stage in scientific accounting researches to improve the existing system of financial reporting. The representatives of company «Arthur Andersen» revealed the main drawbacks of the current accounting system and the audit system of financial reporting, recorded its inability to 
ensure generating qualitative accounting capital information necessary for making investment and loan decisions. That is why scientists paid much attention to solve the problem and that resulted in the development of a number of new reporting models. Most models were analyzed by Institute of Certified Accountants of England and Wales (ICAEW): «The Balanced Scorecard», «The Jenkins Report», «Tomorrow’s Company», «The 21st Century Annual Report», «The Inevitable Change», «Inside Out», «Value Dynamics», "GRI», «The Brookings Institution», «ValueReporting ${ }^{\mathrm{TM}}$, «The Hermes Principles» [10, p. 15-16]. The main idea for such model building was the transformation of content filling and procedure aspects of financial reporting compiling, which includes the principal information about enterprise's capital. But not all the developed models were implemented in practice in the future and were used for building and transformation of national accounting systems, however, some of them became the base for forming the new conception of bookkeeping called integrated.

Considerable role in forming the integrated reporting conception played the three-level model for providing corporation transparency developed by Di Piaza and Jekklz R. («Value Reporting2), its third level is the demands for specific company information, which includes strategy, plans, risk management methods, labour payment principles, corporation management, and the rules for efficiency assessment used by the company [3, p. 36]. The appearance of this particular model was directed to overcome all existing information gaps between entities who create accounting information and its users by considerable increase of amounts of published information and shifts in its content filling. Global recognition of the integrated reporting conception as one of the most active ways of going out of the crisis in bookkeeping development took place in 2011 when The International Integrated Reporting Committee (IIRC) was formed. After publishing of discussion documents (2011) and the prototype of integrated reporting conceptual base (2012) the Committee issued the International Project on integrated reporting in $2013<\mathrm{IR}>$ [9]. The <IR> project determines the main types of capital, namely, financial, industrial, intellectual, human, social and natural, which must be included into the integrated reporting information (p. 2.12). Capital is understood as the form of value keeping, which in any of its forms becomes a contribution to the entity's business model (p. 2.13). Consequently, such an approach expects the use of the extended understanding of capital in accounting not only property (soviet approach) or assets that can bring future economic benefits (market approach), but also inclusion to the structure of capital all those objects that allow to keep the value, which is created as a result of increase, decrease or capital transformation. The determinant peculiarity of the $<\mathrm{IR}>$ project is also that the main users of the integrated reporting are the investors of financial capital (p. 1.5), this scatters the doubts concerning a priority group of integrated reporting users.

So, the development of the integrated reporting conception realized in the <IR> project, is the attempt to overcome the accounting crisis, in particular, in the part of increasing the quality of informing about enterprise's capital. The detailed substantiation of the capital essence, the selection of its kinds and the substantiation of their content filling is a huge step ahead and allows to form the standardized understanding of the problem by researches. Simultaneously, the $\langle\mathrm{IR}>$ project does not solve a great number of issues, which was and at present are paid attention by domestic and foreign scientists. Besides, the introduction of the integrated reporting as a new type of account reporting results in appearance of a considerable amount of organizational and methodical problems.

Functioning of the enterprise according to the sustainable development conception expects the rational use of resources under conditions of their limitation, the use of power saving technologies in scientific progress, and also the creation of qualitative and safety produce.

The integrated reporting is the reporting, which generalizes the information about the financial state and the results of social, charity and ecological activities of an entity and this gives a possibility to assess the efficiency of use of resources and determine the strategy of its development.

In our opinion, the advantages of integrated reporting compiling are the following: a broader perspective of consideration of enterprise's activity; the improvement of enterprise's accounting policy as a result of integration of the principles of sustainable development into the enterprise's activity; increasing the trust of enterprise's workers and consumers in the safety of technological processes and enterprise's produce for the environment.

In spite of the advantages of integrated reporting compiling, it has also its disadvantages:

the absence of developed methodical provision of reporting according to the of sustainable development principles does not ensure the reliability of obtained indices of integrated reporting;

there is no list of indices that can meet information needs of all users, in particular, investors, the state, auditors, society, creditors, consumers, employees, management personnel, academics, and the media;

- the contradiction of the statement that the interests of financial capital investors will meet broader social interests later on, especially taking into account national features of capital market functioning;

- the absence of clear regulation of integrated reporting formation in terms of capital types not paying attention to their proposed classification;

- the absence of clear indications concerning the form of providing information about enterprise's capital

(financial and non-financial);

-the absence of arguments of interconnection of assessment conception according to fair value with assessment approaches, which can be used when integrated reporting compiling; 
- the obscurity of order accounting organization for information formation about separate types of enterprise's capital, namely, natural, social, human, and intellectual that requires from accountants extra occupational capacities;

- unaccounted possibility of arising synergetic effects caused by the use of various types of enterprise's capital that has to be liable to accounting reflection;

- the necessity to develop the integrated reporting audit methodology, especially in the part concerning new types of capital and the information about the types is included into the integrated reporting in financial and nonfinancial forms.

Atamas P.J. and Atamas O.P. consider one of the most significant aspects of criticism for the existing system of corporate reporting is that it does not pay enough attention to such factors as the risks of activities, the development strategy, control and stability in business, enterprise's cost and the perspectives of cost increase, the use of natural resources, and environment conservation, the social aspects of enterprise's activities, etc. In other words, they mean insufficient information or total absence in reporting so called non-financial indices, which play sometimes rather important role in the assessment of enterprise's activity results and its management and in determination of perspectives for further development of a separate business unit, its investment attractiveness [1, p. 78].

We consider the main tasks of integrated reporting to be the following ones:

- providing the information about enterprise's income distribution and enterprise's development strategy;

- enterprise's accounting policy improvement as a result of integration of sustainable development principles into enterprise's activity;

- increase in loyalty of employees and consumers to the safety of technological progress and enterprise's produce for environment;

- the formation of information about separate types of capital, in particular, natural, social, human, and intellectual.

Let us consider the principles of integrated reporting. Bezverhyj $\mathrm{K}$. determines the following principles for integrated reporting compiling: a) strategical direction; b) information coherency; c) orientation for the future; d) reactivity and orientation to the persons concerned; e) substantiality and laconic brevity; f) reliability and coordination; g) completeness and comparability [2, p. 26]. Simultaneously, Jershova N.Ju. highlights such basic principles for integrated reporting compiling: strategical direction and orientation for the future, information coherency, cooperation with the parties concerned, essentiality, brevity, authenticity, completeness, steadiness, comparability, and also such extra principles as synergism, systemacy, constant improvement, balance [5, p. 454]. According to Domashenko Ju.V. the basic principles for integrated reporting are the following: strategical direction, information connection, orientation for the future, information users' reaction and attraction, reliability, essentiality, and clarity [4, p. 69].

We consider the principles for integrated reporting compiling to be the following ones: orientation for the future, essentiality, necessity, integrity, authenticity, completeness, periodicity, succession, timeliness, interpretation, comparability.

Jershova N.Ju. singles out the following integrated reporting structure: 1) examination of organization and environment; 2) management; 3) business model; 4) risks and possibilities; 5) strategy and resource distribution 6 ) activity results; perspectives for the future; the recommendations on reporting preparation and presentation [5, p. 454]. Bezverhyj K. points out to the necessity of the following issues in the integrated reporting: 1) the appeal of individuals provided with management functions; 2) the information about the enterprise; 3) enterprise's management; 4) enterprise's business model; 5) enterprise's activity results; 6) risks and possibilities; 7) audit conclusion [2, p. 26].

In our opinion, the integrated reporting structure should include the following issues: 1) the description of business and environment; 2) accounting policy; 3) the organizational structure of management; 4) a business model; 5) risks and possibilities; 6) net profit distribution strategy and the efficiency of resource use; 7) activity results; 8) perspectives for the future; 9) audit conclusion.

The integrated reporting must include the information about the net profit use; the developed algorithm of its distribution according to the development strategy is shown in Fig.1.

Special attention in the algorithm shown in fig.1. should paid to the direction of net profit to the production development according to three strategies: insufficient renovation, renovation on the level of depreciation and expanded renovation of non-current assets. The choice of non-current assets expanded renovation strategy is the most expedient if the enterprise's management is interested in increasing the scales of enterprise's activities and multiplication of net profit in the future.

Prodanchuk M. considers it is reasonable to establish the following demands to the organization of integrated report publication and setting up connections with interested parties: companies have to show an open dialogue with the public and other circles concerned about financial situation and the results of activities, social development and social investments, ecology of production processes and their influence upon environment to identify their interests; periodicity of preparation and publishing in the media; legislative confirmation of obligation for integrated reporting presentation [8, c. 28-29]. 
ISSN 1994-1749. 2017. Bun. 2 (37).

Проблеми теорії та методологї бухгалтерського обліку, контролю і аналізу

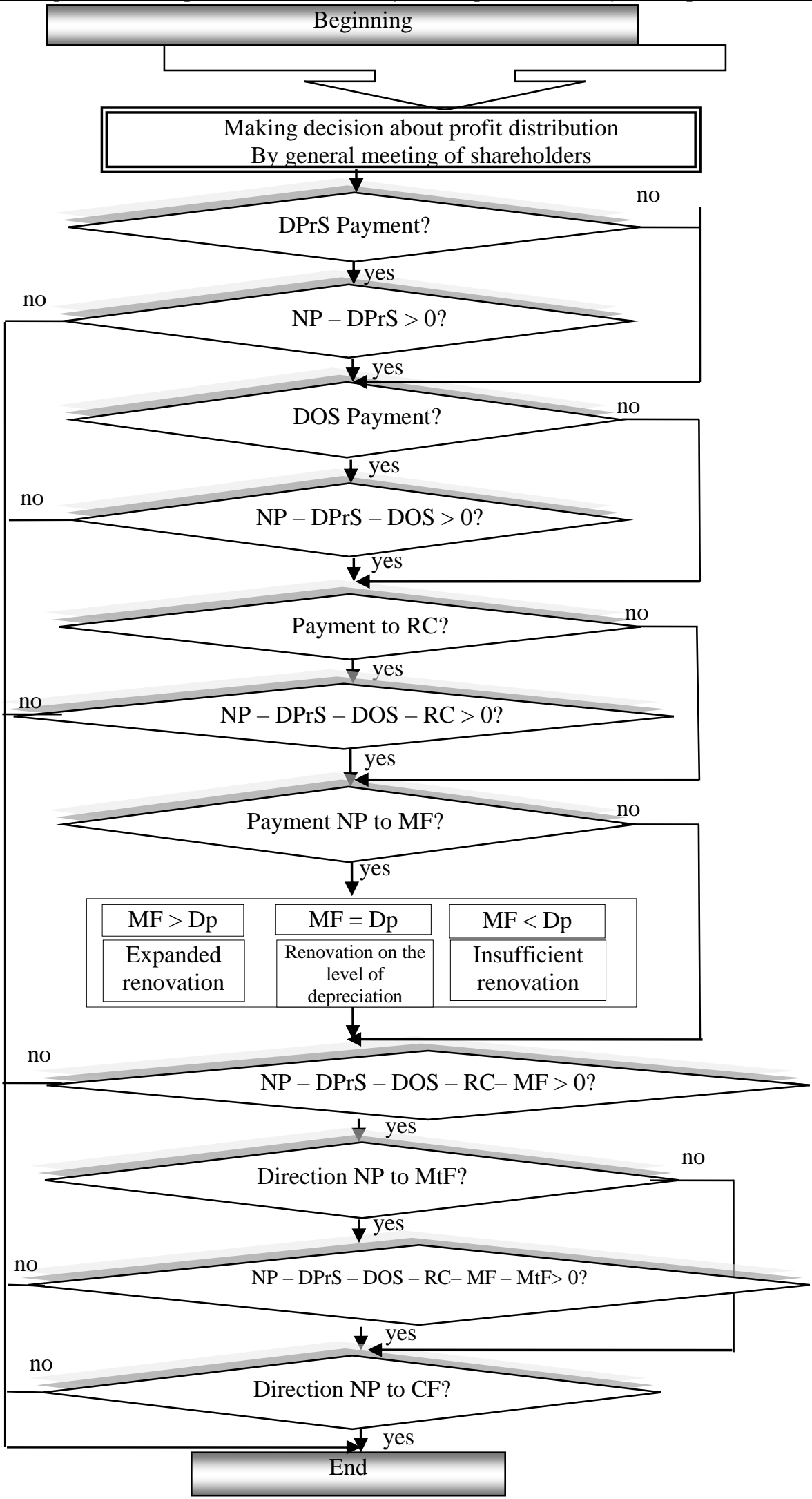

Notes:

$N P$ - net profit; DPrS - dividends on preferred shares; DOS - dividends on ordinary shares; RC - reserve capital; Dp - depreciation; $M F$ - manufacturing fund; $M t F-$ motivational fund; $C T$-charitable trust

Fig. 1. Algorithm of net profit distribution: strategic aspect 
ISSN 1994-1749. 2017. Bun. 2 (37).

Проблеми теорії та методології бухгалтерського обліку, контролю і аналізу

Bezverhyj K. points out to the necessity of obligatory audit of the integrated reporting. The external confirmation of reporting:

- is performed by external groups or individuals whose competence can be shown both in the subject and in the practice of confirmation;

- is realized in a systematical, and documentary way and based on evidence and is described by fixed procedures;

- is assessed or provides balanced and founded description of results taking into account the credibility of data included in it and the general choice of the content;

- is used for performance of groups' or persons' confirmation who are unlimited in their connection with the enterprise or its concerned parties to get independent and reliable decision about reporting and make it public;

- causes the thought which is available in the written form and with the executor's statement that confirms its connection with the enterprise that prepared the reporting. The key aspect of work with the integrated reporting is its assessment and verification by an independent auditor. The auditor's assessment provides the enterprise with the guarantee of the third party about the data published in the reporting are true and reflect the objective reality [2, p. 24-25].

So, integrated reporting compiling requires the extra costs to pay for auditor's firm services to confirm its reliability. It is not reasonable to assess the enterprise's activity using the data included in the integrated reporting without auditor's conclusion.

Conclusions and perspectives of further researches. Researching the approaches to the integrated reporting compiling the following conclusions can be made:

The integrated reporting is that one, which generalizes the information about the financial state and the results of social, charity and ecological activities of an entity and this gives a possibility to assess the efficiency of use of resources and determine the strategy of its development. We consider the principles for integrated reporting compiling to be the following ones: orientation for the future, essentiality, necessity, integrity, authenticity, completeness, periodicity, succession, timeliness, interpretation, comparability.

2. We propose that the integrated reporting structure should include the following issues: 1) the description of business and environment; 2) accounting policy; 3) the organizational structure of management; 4) a business model; 5) risks and possibilities; 6) net profit distribution strategy and the efficiency of resource use; 7) activity results; 8) perspectives for the future; 9) audit conclusion.

3. The main advantages of compiling the integrated reporting are the following: a broader perspective of consideration of the activity; the improvement of accounting policy as a result of integration of the principles of sustainable development into activity; increasing the trust of workers and consumers in the safety of technological processes and products for environment

4. Розроблено алгоритм розподілу чистого прибутку залежно від стратегій розвитку підприємства. Під час спрямування чистого прибутку на розвиток виробництва можливі три стратегії: недостатнє оновлення, оновлення на рівні зносу та розширене оновлення необоротних активів. Вибір стратегії розширеного оновлення необоротних активів дозволить збільшити масштаби діяльності та примножити чистий прибуток. Перспективами подальших досліджень $є$ розробка методики аудиту інтегрованої звітності.

We developed the algorithm of net profit distribution according to the strategies of enterprise's development. Directing net profit to the development of production three strategies are possible: insufficient renovation, renovation on the level of depreciation and expanded renovation of non-current assets. The choice of non-current assets expanded renovation strategy will allow to increase the scales of enterprise's activities and multiply its net profit. The perspectives of further researches is to develop the integrated reporting methodology.

\section{Список використаної літератури:}

1. Атамас П.Й. Інтегрована корпоративна звітність: проблеми впровадження / П.Й. Атамас, О.П. Атамас // Академічний огляд. - 2015. - № 1. - С. 78-85.

2. Безверхий $K$. Інтегрована звітність підприємства: удосконалення організації і методики іiі складання / К.Безверхий // Бухгалтерський облік і аудит. - 2014. - № 5. - С. 23-28.

3. Ди Пиаза С. Будущее корпоративной отчетности. Как вернуть доверие общества / С.Ди Пиаза, Р.Экклз. - М. : Альпина Паблишер, 2003. - 212 с.

4. Домашенко Ю.В. Інтегрована звітність: вдосконалений облік операцій як показник ефективності діяльності / Ю.В. Домашенко // Економічний вісник Національного гірничого університету. 2013. - № 1. - C. 65-72.

5. Сршова Н.Ю. Розвиток методологічних основ формування інтегрованої звітності / Н.Ю. Сршова // Науковий вісник Ужгородського університету / Серія : Економіка. - 2016. - Вип. 1 (47). C. $451-459$. 
ISSN 1994-1749. 2017. Bun. 2 (37).

Проблеми теорії та методології бухгалтерського обліку, контролю і аналізу

6. Костирко Р.О. Інтегрована звітність - інструмент соціально відповідального бізнесу / Р.О. Костирко // Часопис економічних реформ. - 2014. - № 1. - С. 49-54.

7. Лоханова Н.О. Інтегрована звітність як продукт цілісної обліково-аналітичної системи / Н.О. Лоханова // Вісник соціально-економічних досліджень. - 2012. - Вип. 4. - С. 50-56.

8. Проданчук М. Інтегрована звітність - інструмент управління підприємством / М.Проданчук // Бухгалтерський облік і аудит. - 2014. - № 2. - С. 24-31.

9. Проект міжнародного формату інтегрованої звітності $<\mathrm{IR}>$. - BDO, 2013. - 49 с.

10. New Reporting Models for Business. Information for Better Markets Initiative. - London : ICAEW, 2003. $-78 \mathrm{p}$.

\section{References:}

1. Atamas, P.J. and Atamas, O.P. (2015), «Integrovana korporatyvna zvitnist': problemy vprovadzhennja», Akademichnyj ogljad, No. 1, pp. 78-85.

2. Bezverhyj, K. (2014), «Integrovana zvitnist' pidpryjemstva: udoskonalennja organizacii' i metodyky i'i' skladannja», Buhgalters'kyj oblik $i$ audit, No. 5, pp. 23-28.

3. Di Piaza, S. and Jekklz, R. (2003), Budushhee korporativnoj otchetnosti. Kak vernut' doverie obshhestva, Al'pina Pablisher, Moskva, 212 p.

4. Domashenko, Ju.V. (2013), «Integrovana zvitnist': vdoskonalenyj oblik operacij jak pokaznyk efektyvnosti dijal'nosti», Ekonomichnyj visnyk Nacional'nogo girnychogo universytetu, No. 1, pp. 65-72.

5. Jershova, N.Ju. (2016), «Rozvytok metodologichnyh osnov formuvannja integrovanoi' zvitnosti», Naukovyj visnyk Uzhgorods'kogo universytetu, Serija Ekonomika, Vol. 1 (47), pp. 451-459.

6. Kostyrko, R.O. (2014), «Integrovana zvitnist' - instrument social'no vidpovidal'nogo biznesu», Chasopys ekonomichnyh reform, No. 1, pp. 49-54.

7. Lohanova, N.O. (2012), «Integrovana zvitnist' jak produkt cilisnoi' oblikovo-analitychnoi' systemy», Visnyk social'no-ekonomichnyh doslidzhen', Vol. 4, pp. 50-56.

8. Prodanchuk, M. (2014), «Integrovana zvitnist' - instrument upravlinnja pidpryjemstvom», Buhgalters'kyj oblik i audit, No. 2, pp. 24-31.

9. Proekt mizhnarodnogo formatu integrovanoi' zvitnosti $\langle I R\rangle(2013)$, BDO, 49 p.

10. New Reporting Models for Business. Information for Better Markets Initiative (2003), ICAEW, London, $78 \mathrm{p}$.

LEGENCHUK Sergiy Fedorovych - PhD in Economics, Professor, Head of the Department of Audit and Accounting at Zhytomyr State Technological University.

Scientific interests:

- development of theory and methodology in accounting;

- positive accounting theory;

- intangible assets accounting.

POLISHCHUK Iryna Romanivna - Cand. Ec. Sc., Associate Professor, Associate Professor of the audit and accounting department at Zhytomyr State Technological University.

Scientific interests:

- $\quad$ accounting and analytical provision of forecasting the size of corporative rights of members

- methodology of strategic analysis

- $\quad$ accounting and analytical provision of produce calculating

The article was sent to the publishing department on 05.05.2017. 